\title{
BIBECHANA
}

ISSN 2091-0762 (Print), 2382-5340 (Online)

Journal homepage: http://nepjol.info/index.php/BIBECHANA

Publisher: Department of Physics, Mahendra Morang A.M. Campus, TU, Biratnagar, Nepal

\section{Structural analysis of Cu substituted NilZn in Ni-Zn Ferrite}

\author{
D. Parajuli ${ }^{1,2 *}$, K. Samatha ${ }^{2}$ \\ ${ }^{1}$ Department of Physics, Tri-Chandra Multiple Campus, Tribhuvan University, Kathmandu, Nepal. \\ ${ }^{2}$ Department of Physics, College of Science and Technology, Andhra University, Visakhapatnam, India. \\ *Email:_deepenparaj@gmail.com
}

\section{Article Information:}

Received: June 15, 2020

Accepted: July 31, 2020

\section{Keywords:}

$\mathrm{Ni}-\mathrm{Zn}$ ferrite

$\mathrm{Cu}$ substituted $\mathrm{Ni}$

Cu substituted $\mathrm{Zn}$

XRD

Single phase spinel

\begin{abstract}
$\mathrm{Ni}-\mathrm{Zn}$ ferrites are soft ferrites basically popular for high frequency devices. They have low coercivity, low permeability and higher resistivity. These properties have their own benefits on one hand but on the other hand, we can make them more efficient by doping suitable element in order for tuning their properties for other applications. It this work, highly conducting $\mathrm{Cu}$ is used for substituting $\mathrm{Ni}$ in Ni-Zn ferrites and prepared $\mathrm{Ni}_{0.5-\mathrm{x}} \mathrm{Cu}_{\mathrm{x}} \mathrm{Zn}_{0.5} \mathrm{Fe}_{2} \mathrm{O}_{4}(\mathrm{x}=0,0.05,0.1,0.15$ and 0.2) samples using the sol-gel auto-combustion process. We have studied their resulting structural parameter using X-ray Powder Diffraction (XRD) and Fourier Transform Infrared (FTIR) Spectroscopy method and compared with that of $\mathrm{Cu}$ substituted $\mathrm{Zn} \mathrm{Ni-Zn} \mathrm{ferrites.} \mathrm{Their} \mathrm{structures} \mathrm{are} \mathrm{found} \mathrm{to} \mathrm{be} \mathrm{single} \mathrm{phase} \mathrm{cubic}$ spinel similar to that of $\mathrm{Cu}$ substituted $\mathrm{Zn}$. The lattice constant increases with $\mathrm{Cu}$ concentration opposite to that at $\mathrm{Zn}$ substitution. Likewise, the size of the crystallites were not in monotonic change with the doping concentration in both cases due to internal strain and cation distribution. The difference in the pattern of XRD and FTIR of our samples indicate their different but significant properties. The changes in the structure shows the effect of $\mathrm{Cu}$ doping and indicates the possible interesting changes in their electric, electronic and magnetic properties.
\end{abstract}

DOI: https://doi.org/10.3126/bibechana.v18i1.29475

This work is licensed under the Creative Commons CC BY-NC License. https://creativecommons.org/licenses/by-nc/4.0/

\section{Introduction}

Ferrites have general structure $\mathrm{A}^{2+} \mathrm{Fe}_{2}{ }^{3+} \mathrm{O}_{4}{ }^{2}$ which are the structure under spinel with general formula $\mathrm{AB}_{2} \mathrm{X}_{4}$. Here, $\mathrm{A}$ and $\mathrm{B}$ are various divalent and trivalent metal cations and, $\mathrm{X}$ is $\mathrm{O}, \mathrm{S}$, Se etc. ' $\mathrm{A}$ ' cation covers $1 / 8^{\text {th }}$ of the tetrahedral holes and ' $\mathrm{B}$ ' covers $1 / 2$ of the octahedral holes. They are easy to synthesize and have simple structure for analysis. The spinel nanoferrites are useful in the fields like microwave devices, ultra-high-density magnetic encoding, coating, etc. [1-3]. They have crystallographic structure which can bring feasible change in their microstructure and electromagnetic characteristics. The study of the shape and material properties of different composition of $\mathrm{Ni}-\mathrm{Cu}-\mathrm{Zn}$ ferrite system is increasing these days [4-7]. Magnetic nanoparticles (NPs) of $\mathrm{Cu}^{2+}$ added Nickel-Zinc magnetic oxides are commonly utilized in magnetic component like rotary DY 
core, transformer and magnetic inductive core etc. In the present study, it is planned to formulate NPs of $\mathrm{Cu}$ substituted $\mathrm{Ni}$ in Ni-ZN ferrites containing iron oxide as their main components using sol-gel method and compare their structure with $\mathrm{Cu}$ substituted $\mathrm{Zn}$ in Ni-ZN ferrites [8]. Their investigation on $\mathrm{Cu}$ substituted $\mathrm{Zn}$ shows that $\mathrm{Cu}$ substituted $\mathrm{Zn}$ in Ni-ZN ferrites is appropriate for Multilayer Chip Inductor (MLCI) as magnetic material. The structural investigation of our compositions is carried out by utilizing $\mathrm{X}$-ray diffraction (XRD) and Fourier Transform Infrared (FTIR) spectroscopy.

\section{Materials and Method}

Copper substituted Ni-Zn NPs are prepared by solgel auto-combustion method as the precursors under considerations react readily with water and can form colloidal solution. Moreover, the process is easy, simple, cheap and densification takes place comparatively at lower temperature giving chemically homogeneous sample. The starting materials are A grade $99.99 \%$ pure Nickel nitrate, Copper nitrate, Zinc nitrate, Iron nitrate and Citric acid monohydrate with molecular formula $(\mathrm{Ni}$ $\left.\left(\mathrm{NO}_{3}\right)_{2} \cdot 6 \mathrm{H}_{2} \mathrm{O}\right), \mathrm{Cu}\left(\mathrm{No}_{3}\right)_{3} \cdot \mathrm{H}_{2} \mathrm{O},\left(\mathrm{Zn}\left(\mathrm{NO}_{3}\right)_{2} \cdot 6 \mathrm{H}_{2} \mathrm{O}\right)$, $\left(\mathrm{Fe}\left(\mathrm{NO}_{3}\right)_{3} \cdot 9 \mathrm{H}_{2} \mathrm{O}\right)$ and $\left(\mathrm{C}_{6} \mathrm{H}_{8} \mathrm{O}_{7} \cdot \mathrm{H}_{2} \mathrm{O}\right)$ respectively supplied by Himedia and Merk India. The ferrites $\mathrm{Ni}_{0.5-\mathrm{x}} \mathrm{Cu}_{\mathrm{x}} \mathrm{Zn}_{0.5} \mathrm{Fe}_{2} \mathrm{O}_{4}$ samples with $\mathrm{x}=0.0,0.05$, $0.1,0.15$ and 0.2 are prepared. The mixture of these metal nitrates and citric acid were mixed in molar ratio 1:1 and were dissolved in the distilled water to get clear solution. The solution was made neutral by adding liquid ammonia and then stirred in magnetic stirrer maintained at $100^{\circ} \mathrm{C}$ for $4 \mathrm{hr}$. They were then decanted and dried at normal temperature for $40 \mathrm{hrs}$. The flakes thus obtained were combusted and converted into a powder. The powder was sintered in a muffle furnace at $800{ }^{\circ} \mathrm{C}$ for $4 \mathrm{~h}$ at $5 \% \mathrm{~min}$ and was used for testing several properties. We have used Rigaku X-ray diffractometer (Rigaku Miniflex II) incorporated with $\mathrm{Cu}-\mathrm{K} \alpha$ radiation of wavelength $1.5406 \AA$ and
FTIR (IR Prestige21, Shimadzu, Japan) for their structural property in Analytical Research Laboratory, AU.

\section{Result and Discussion}

\section{X-Ray Diffraction}

The XRD plots of different $\mathrm{Ni}_{0.5-\mathrm{x}} \mathrm{Cu}_{\mathrm{x}} \mathrm{Zn}_{0.5} \mathrm{Fe}_{2} \mathrm{O}_{4}(\mathrm{x}$ $=0.0,0.05,0.1,0.15$ and 0.2$)$ samples are shown in figure 1 showing single phase cubic spinel structure according to the JCPDS card No.48- 0489 standard under $F d-3 m$ group. The lattice constant ' $\mathrm{a}$ ' is determined with the following relation [9]:

$$
\mathrm{a}=\mathrm{d}_{\mathrm{hkl}} \sqrt{\mathrm{h}^{2}+\mathrm{k}^{2}+\mathrm{l}^{2}}
$$

where, $d_{h k l}$ is interplaner spacing for given hkl planes and is calculated by Bragg's law.

The plot of intensity against the diffracting angle

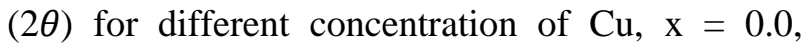
$0.05,0.1,0.15$ and 0.2 in $\mathrm{Ni}_{0.5-\mathrm{x}} \mathrm{Cu}_{\mathrm{x}} \mathrm{Zn}_{0.5} \mathrm{Fe}_{2} \mathrm{O}_{4}$ ferrite (NPs) are shown in figure 1. The sharp peaks in the pattern shows the crystalline nature of the sample. The highest intensity (311) peak indicates the appropriate orientation in order to find the average crystallite size of all samples [10]. The peaks are almost similar with that of $\mathrm{Cu}$ substituted $\mathrm{Zn}$ as shown in figure 2 . The maximum intensity with corresponding diffracting angle in each concentration is as shown in figure 3 . The overall effect is the decrease in the maximum intensity and shifting of maxima towards lower angle side with the increment in the concentration of copper. This is due the change in ionic radii and size of crystallite.

The Debye-Scherer's formula gives the average size of the crystallite size [11].

$$
D_{311}=\frac{0.9 \lambda}{\beta \cos \theta}
$$

where, $D_{311}, \lambda, \beta$ and $\theta$ are volume-averaged crystallite size, wavelength of X-ray (1.5406 $)$, full width at half maximum of (311) peak and diffraction angle respectively. 


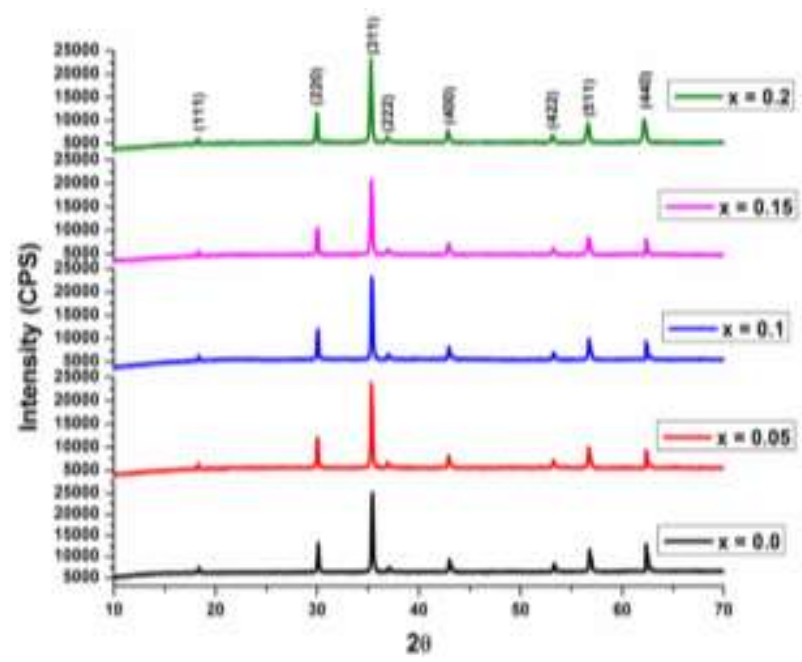

Fig.1: X-ray diffraction patterns of $\mathrm{Ni}_{0.5-x} \mathrm{Cu}_{x} \mathrm{Zn}_{0.5}$ $\mathrm{Fe}_{2} \mathrm{O}_{4}(x=0.0$ to 0.2$)$ ferrites NPs.

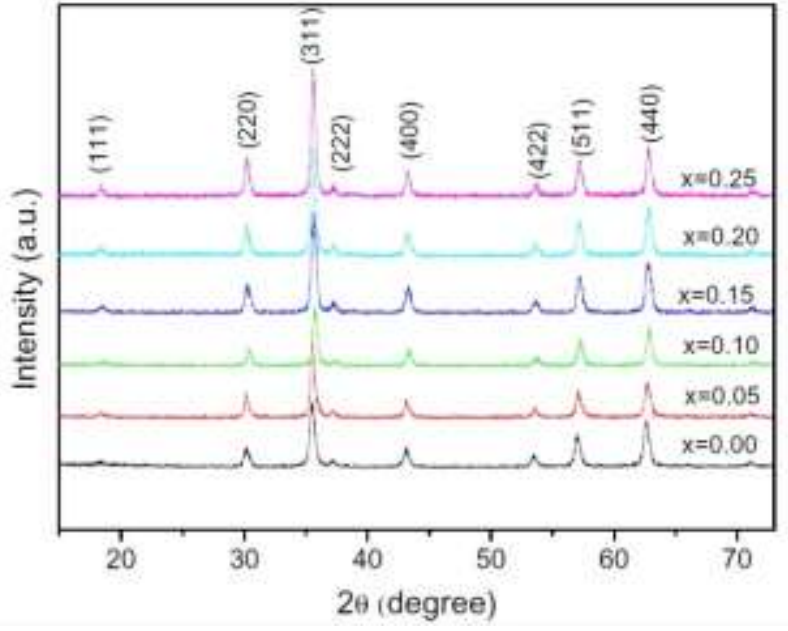

Fig. 2: X-ray diffraction patterns of $\mathrm{Ni}_{0.5} \mathrm{Cu}_{x} \mathrm{Zn}_{0.5}$ ${ }_{x} \mathrm{Fe}_{2} \mathrm{O}_{4}(x=0.0$ to 0.2$)$ ferrites NPs [8].

The crystallite size, lattice parameters and cell volume of the composition $\mathrm{Ni}_{0.5-\mathrm{x}} \mathrm{Cu}_{\mathrm{x}} \mathrm{Zn}_{0.5} \mathrm{Fe}_{2} \mathrm{O}_{4}$ ( $\mathrm{x}$ $=0.0,0.05,0.1,0.15$ and 0.2$)$ are listed in Table 1 . The crystallite size ranges from 29.01 to $42.68 \mathrm{~nm}$ in random order. There are mainly three factors responsible in these random changes: 1 . synthesis condition (almost constant in our case) 2. Stress created on adsorption (ion substitution process expands lattice parameter thereby generating inter stress and distortion in the lattice structure and hence affects the crystal growth rate and crystallite size) and 3. Energy difference between metaloxygen bond (lower energy) and Fe-oxygen bonds (higher energy).

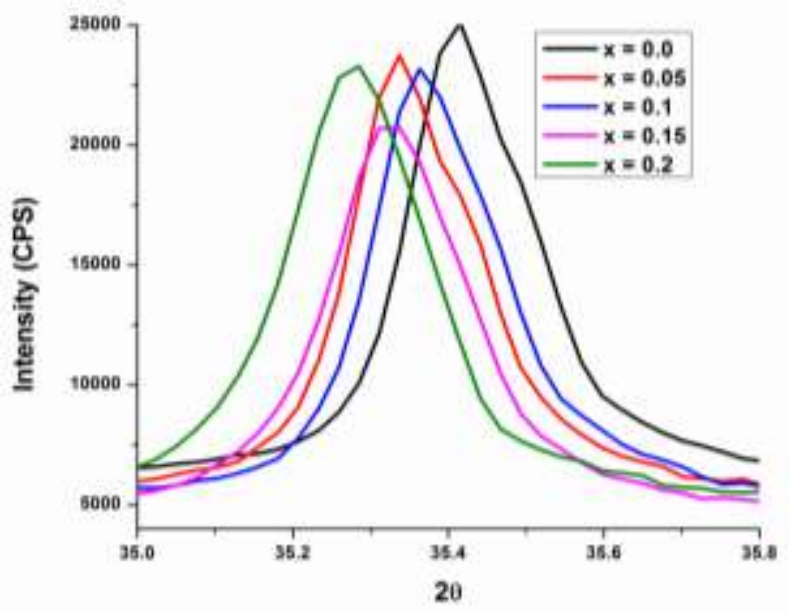

Fig. 3: XRD patterns of Maximum Intensity vs Angle $\mathrm{Ni}_{0.5-\mathrm{x}} \mathrm{Cu}_{\mathrm{x}} \mathrm{Zn}_{0.5} \mathrm{Fe}_{2} \mathrm{O}_{4}(\mathrm{x}=0.0,0.05,0.1,0.15$ and 0.2) ferrites NPs.

Initially at lower concentration, the increase in lattice parameter due to the $\mathrm{Cu}^{+2}$ entrance creates internal stress, decreases the growth rate of crystal and hence reduce the crystallite size [12]. As the concentration increases further, lower energy requirement for their bonding with oxygen accelerate the growth process thereby increasing the crystallite size. After sufficient bonding, the cations now begins to move from one denser site to another site sometimes with distortion of bond thereby decreasing the growth process. Simultaneously, the lattice compression takes place due to the partial oxidation of $\mathrm{Ni}^{2+}$ to $\mathrm{Ni}^{3+}, \mathrm{Cu}^{2+}$ to $\mathrm{Cu}^{3+}$ [13-15]. The crystallite size and lattice parameter variation with concentration is as shown in figure 4 and figure 5 for $\mathrm{Cu}$ substituted $\mathrm{Ni}$ and $\mathrm{Cu}$ substituted $\mathrm{Zn}$ respectively.

The lattice parameter increases with the $\mathrm{Cu}^{2+}$ ions concentration. This is due to the larger ionic radius of $\mathrm{Cu}^{2+}$ ions $\left(0.73 \mathrm{~A}^{\circ}\right)$ [16] as compared $\mathrm{Ni}^{2+}(0.69$ $\AA$ ) [17] thereby expanding the unit cell or increasing lattice constant [18]. The reverse pattern is obtained in case of $\mathrm{Cu}$ substituted $\mathrm{Zn}$ as $\mathrm{Zn}^{2+}\left(0.74^{\circ} \mathrm{A}\right)$ has more ionic radius than that of $\mathrm{Cu}^{2+}\left(0.73 \mathrm{~A}^{\circ}\right)$. In some cases, the lattice constant do not show the usual response if $\mathrm{Cu}$ replace $\mathrm{Zn}$ in the octahedral site [19]. The variation of lattice constant is more significant in smaller size of NPs. 
From Scherer's formula, the diffraction peak width $(\beta)$ is inversely proportional to the size of the crystallite. The increase in the lattice parameter expand the volume of unit cell accordingly. Decreasing in crystallite size enhances sintering which inturn decreases the lattice defects and involved strain but facilitate the coalition of the crystals resulting the increase in particle size.

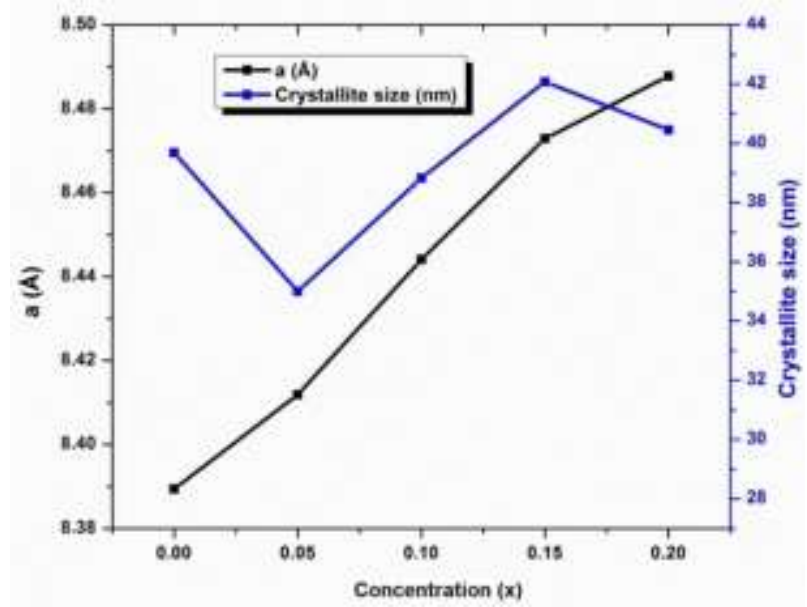

Fig. 4: Variation of lattice constant and crystallite size of $\mathrm{Ni}_{0.5-\mathrm{x}} \mathrm{Cu}_{\mathrm{x}} \mathrm{Zn}_{0.5} \mathrm{Fe}_{2} \mathrm{O}_{4}(\mathrm{x}=0.0,0.05,0.1,0.15$ and 0.2) ferrites NPs.

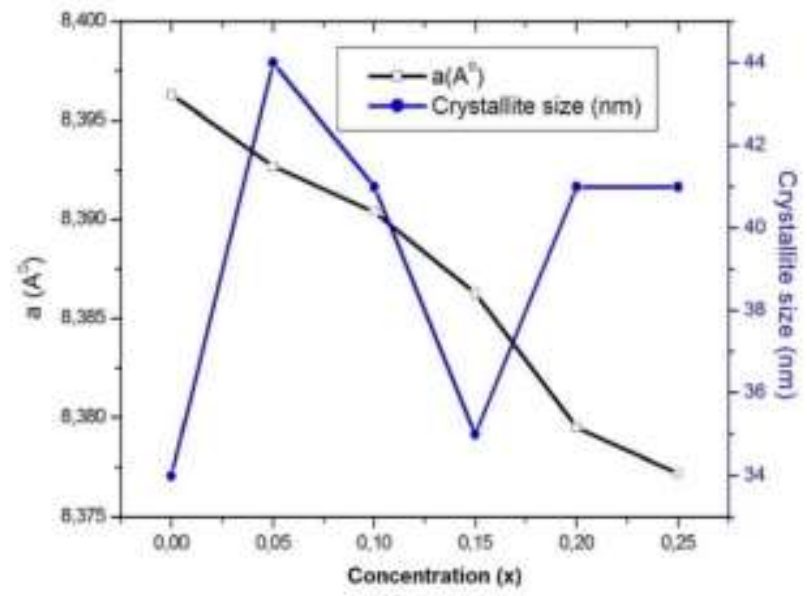

Fig. 5: Variation of lattice parameters with composition of $\mathrm{Ni}_{0.5} \mathrm{Zn}_{0.5-\mathrm{x}} \mathrm{Cu}_{\mathrm{x}} \mathrm{Fe}_{2} \mathrm{O}_{4}$ sample ( $\mathrm{x}=$ $0.0,0.05,0.1,0.15$ and 0.2 ) ferrites NPs (data [8]).

\section{FTIR spectroscopy}

The ambiguity created in the structural parameters like crystallite size variation with concentration, can be resolved by the FTIR spectroscopy. It gives the exact information about cation distribution or the functional group and the force creating vibration in the crystal by which absorption and diffraction takes place.

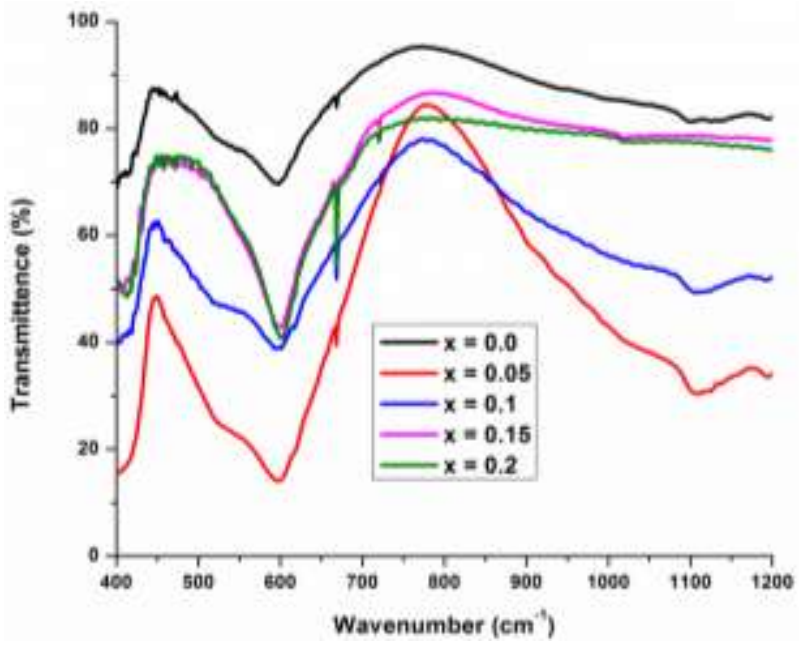

Fig. 6: IR spectra of of $\mathrm{Ni}_{0.5-\mathrm{x}} \mathrm{Cu}_{\mathrm{x}} \mathrm{Zn}_{0.5} \mathrm{Fe}_{2} \mathrm{O}_{4}(\mathrm{x}=$ $0.0,0.05,0.1,0.15$ and 0.2 ) ferrite NPs.

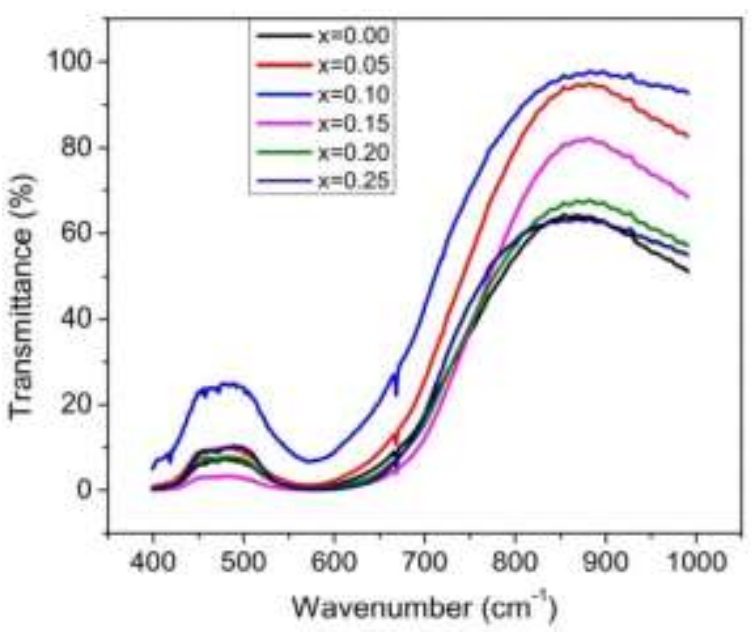

Fig. 7: IR spectra of of $\mathrm{Ni}_{0.5-\mathrm{x}} \mathrm{Cu}_{\mathrm{x}} \mathrm{Zn}_{0.5} \mathrm{Fe}_{2} \mathrm{O}_{4}(\mathrm{x}=$ $0.0,0.05,0.1,0.15$ and 0.2 ) ferrite NPs [8].

The frequency or wave number of the vibration depends on lattice parameter, lattice spacing, masses of cations and cation oxygen bonding. There are two absorption bands $\boldsymbol{v}_{1}$ and $\boldsymbol{v}_{2}$ around $400 \mathrm{~cm}^{-1}$ to $600 \mathrm{~cm}^{-1}$ due to two tetrahedral and octahedral sites with A-O-A and B-O-B bond vibration respectively as shown in figure 6 for $\mathrm{Cu}$ substituted $\mathrm{Ni}$ and figure 7 for $\mathrm{Cu}$ substituted $\mathrm{Zn}$ respectively. The substitution of $\mathrm{Cu}$ shifted the absorption bands of both tetrahedral and octahedral 
sites slightly towards high frequency region as mentioned in Table 2. As the bond length increases, the frequency decreases as usual. The IR spectra analysis shows the $\mathrm{Cu}^{2+}$ ions in the octahedral site as in figure 6. The spectra of $\mathrm{Cu}$ substituted $\mathrm{Zn}$ is similar but the absorption is more indicating high atomic weight element in the composition. The study of force constants gives the complete information of cation distribution.

Table 1: Lattice parameters of $\mathrm{Ni}_{0.5-\mathrm{x}} \mathrm{Cu}_{\mathrm{x}} \mathrm{Zn}_{0.5} \mathrm{Fe}_{2} \mathrm{O}_{4}(\mathrm{x}=0.0,0.05,0.1,0.15$ and 0.2$)$ ferrites NPs.

\begin{tabular}{|c|l|c|c|}
\hline $\begin{array}{c}\text { Concentration } \\
(\mathbf{x})\end{array}$ & \multicolumn{1}{|c|}{ Compounds } & $\begin{array}{c}\text { Tetrahedral absorption } \\
\text { bands } \boldsymbol{v}_{\boldsymbol{I}}(\mathbf{c m}\end{array}$ & $\begin{array}{c}\text { Octahedral absorption } \\
\text { bands } \boldsymbol{v}_{\mathbf{2}}(\mathbf{c m}\end{array}$ \\
\hline 0.0 & $\mathrm{Ni}_{0.5} \mathrm{Zn}_{0.5} \mathrm{Fe}_{2} \mathrm{O}_{4}$ & 402.1 & 580.4 \\
\hline 0.05 & $\mathrm{Ni}_{0.45} \mathrm{Cu}_{0.05} \mathrm{Zn}_{0.5} \mathrm{Fe}_{2} \mathrm{O}_{4}$ & 403.2 & 583.2 \\
\hline 0.1 & $\mathrm{Ni}_{0.4} \mathrm{Cu}_{0.1} \mathrm{Zn}_{0.5} \mathrm{Fe}_{2} \mathrm{O}_{4}$ & 405.6 & 586.0 \\
\hline 0.15 & $\mathrm{Ni}_{0.35} \mathrm{Cu}_{0.15} \mathrm{Zn}_{0.5} \mathrm{Fe}_{2} \mathrm{O}_{4}$ & 408.2 & 590.2 \\
\hline 0.2 & $\mathrm{Ni}_{0.30} \mathrm{Cu}_{0.2} \mathrm{Zn}_{0.5} \mathrm{Fe}_{2} \mathrm{O}_{4}$ & 406.1 & 599.3 \\
\hline
\end{tabular}

Table 2: Tetrahedral and Octahedral absorption bands of $\mathrm{Ni}_{0.5-\mathrm{x}} \mathrm{Cu}_{\mathrm{x}} \mathrm{Zn}_{0.5} \mathrm{Fe}_{2} \mathrm{O}_{4}$ ferrite NPs.

\begin{tabular}{|c|c|c|c|c|}
\hline $\begin{array}{c}\text { Concentration } \\
(\mathbf{x})\end{array}$ & $\boldsymbol{a}(\stackrel{\AA}{\mathbf{A}})$ & $\begin{array}{c}\text { Cell Volume }=\boldsymbol{a}^{\mathbf{3}} \\
(\text { for cubic })(\mathbf{\AA})^{3}\end{array}$ & $\begin{array}{c}\text { Crystallite size } \\
(\mathbf{n m})\end{array}$ & $\begin{array}{c}\text { Space } \\
\text { Group }\end{array}$ \\
\hline 0.0 & 8.3894 & 590.4562 & 42.68 & $F d-3 m$ \\
\hline 0.05 & 8.4119 & 595.2349 & 29.01 & $F d-3 m$ \\
\hline 0.1 & 8.4441 & 602.0943 & 38.83 & $F d-3 m$ \\
\hline 0.15 & 8.4729 & 608.2724 & 42.08 & $F d-3 m$ \\
\hline 0.2 & 8.4878 & 611.4938 & 40.45 & $F d-3 m$ \\
\hline
\end{tabular}

\section{Conclusions}

Diffraction peaks in the XRD pattern show the sample as single phase cubic spinel and the overall effect of the diffraction pattern shows that the maximum intensity peak is moving towards the lower angle side with the concentration of $\mathrm{Cu}$ due to the reduction in ionic radii similar to that of $\mathrm{cu}$ substituted $\mathrm{Zn}$. The random pattern of crystallite size is due to the non-uniform lattice strain caused by cation distribution during doping. The lattice parameter increases with the $\mathrm{Cu}^{2+}$ ions concentration due to the larger ionic radius of $\mathrm{Cu}^{2+}$ ions $\left(0.73 \mathrm{~A}^{\circ}\right)$ as compared to $\mathrm{Ni}^{2+}(0.69 \AA)$ thereby increasing lattice constant. FTIR supports the XRD results with slight shifting in higher frequency side due to $\mathrm{Cu}$ doping.

Finally, the structural properties of Ni-Zn soft ferrites after doping with Copper substituting with
$\mathrm{Ni}$ and $\mathrm{Zn}$ respectively shows opposite trend for lattice parameter and random crystallite size, and different absorption intensity but with similar single phase cubic spinel structure. The differences in structure between the compositions indicates interesting electric and magnetic properties for further study.

\section{References}

[1] S. Yu, G. Wu, X. Gu, J. Wang, Y. Wang, H. Gao J. Ma, Magnetic and $\mathrm{pH}$-sensitive nanoparticles for antitumor drug delivery, Colloids Surf. 103 (2013) $15-22$. http://doi.org/10.1016/j.colsurfb.2012.10.041

[2] Y. Tejabhiram, R. Pradeep, A. T. Helen, C. Gopalakrishnan, C. Ramasamy, Synthesis and magnetic properties of gadolinium substituted zinc ferrites, Mater. Res. Bull. 60 (2014)778-82. https://doi.org/10.1016/j.matlet.2016.11.083 
[3] D. K. Jha, M. Shameem, A. B. Patel, A. Kostka, P. Schneider, A. Erbe, P. Deb, Simple synthesis of superparamagnetic magnetite nanoparticles as highly efficient contrast agent, Mater. Lett. 95 (2013)186-189.

https://doi.org/10.1016/j.matlet.2012.12.096

[4] S. Kenouche, J. Larionova, N. Bezzi, Y. Guari, N. Bertin, M. Zanca, L. Lartigue, M. Cieslak, C. Godin, C. Goze-Bac, NMR investigation of functionalized magnetic nanoparticles Fe 304 as $\mathrm{T} 1-\mathrm{T} 2$ contrast agents, Powder Technol. $225 \quad$ (2014) 60-5. https://doi.org/10.1016/j.powtec.2013.07.038

[5] F. Geinguenaud, I. Souissi, R. Fagard, L. Motte, Y. Lalatonne, Electrostatic assembly of a DNA superparamagnetic nano-tool for simultaneous intracellular delivery and in situ monitoring, Nanomed. Nanotechnol. Biol. Med. 8 (2012) 110615. https://doi.org/10.1016/j.nano.2011.12.010

[6] Ji Hyun Min, Mi-Kyung Woo, Ha Young Yoon, Jin Woo Jang, Jun Hua Wu, Chae-Seung Lim, Young Keun Kim, Isolation of DNA using magnetic nanoparticles coated with dimercaptosuccinic acid, Anal. Biochem. $447 \quad$ (2014) 114-8. https://doi.org/10.1016/j.ab.2013.11.018

[7] A. Drmota, J. Koselj, M. Drofenik, A. Znidarsic, Electromagnetic wave absorption of polymeric nanocomposites based on ferrite with a spinel and hexagonal crystal structure, J. Magn. Magn. Mater 324 (2012)1225-9. https://doi.org/10.1016/j.jmmm.2011.11.015

[8] D. Venkatesh, K. V. Ramesh, Structural and electrical properties of $\mathrm{Cu}$-doped $\mathrm{Ni}-\mathrm{Zn}$ nanocrystalline ferrites for MLCI applications, Modern Physics Letters B 31 (33) (2017) 1750318. http://doi.org/10.1142/S0217984917503183

[9] B. D. Cullity, Elements of X-ray diffraction, Addison Wesley Publication reading, M.A. (1956) http://www.eng.uc.edu/ beaucag/Classes/XRD/ele mentsofxraydi030864mbp.pdf

[10] A .C. F. M .Costa, A .M. D.Leite, H. S. Ferreira, R. H. G. A. Kiminami, S. Cava, L. Gama, Brown pigment of the nanopowder spinel ferrite prepared by combustion reaction, J Eur. Ceram. Soc. 28 (2008) 2033-2037. https://doi.org/10.1016/j.jeurceramsoc.2007.12.039

[11] I. C. Nlebedim, K. W. Dennis, R. W. McCallum, and D. C. Jiles, Structural and magnetic properties of $\mathrm{Ti} 4+/ \mathrm{Co} 2+$ co-substituted cobalt ferrite, J. Appl. Phys. $115 \quad$ (2014)
17 A 519.

https://doi.org/10.1063/1.4866230

[12] J. Peng, M. Hojamberdiev, Y. Xu, B. Cao, J. Wang, H. Wu, Hydrotherm, Synthesis and Magnetic properties of gadolinium-doped $\mathrm{CoFe}_{2} \mathrm{O}_{4}$ nanoparticles, J. Magn. Magn. Mater. 323 (2011) 133-137.

https://doi.org/10.1016/j.jmmm.2010.08.048

[13] Y.-R. Luo, Comprehensive handbook of chemical bond energies, CRC press, Boca Raton, (2007). https://doi.org/10.1201/9781420007282

[14] H. W. Wang, S. C. Kung, Crystallization of Nanosized Ni-Zn Ferrite Powders Prepared by Hydrothermal Method, J. Magn. Magn. Matter 270 (2004) 230-236. https://doi.org/:10.1016/j.jmmm.2003.09.019

[15] M. Nahid, A. Reza, A. Bagher, K. Parviz, Competition between the impact of cation distribution and crystallite size on properties of MnxFe3-xO4 nanoparticles synthesized at room temperature, Cer. Int. 43-17 (2017) 15381-15391. https://doi.org/10.1016/j.ceramint.2017.08.079

[16] Caterina G. C. M. Netto, Henrique E. Toma, Leandro H. Andrade, Superparamagnetic nanoparticles as versatile carriers and supporting materials for enzymes. Mol. Catal. B Enzym. 85-86 (2013) 71-92.

https://doi.org/10.1016/j.molcatb.2012.08.010

[17] F. Guo, Z. Fang, C. C. Xu, R. L. Smith, Solid acid mediated hydrolysis of biomass for producing biofuels, Prog Energy Combust Sci, Oxford, Inglaterra, GB $38 \quad$ (5) (2012) 672-90. http://sourcedb.xtbg.cas.cn/yw/ywlw/201205/P020 120523400633782900.pdf

[18] H. Jing, X. Wang, Y. Liu, A. Wang, Coppercobalt Bimetallic Oxides-doped Alumina Hollow Spheres: A Highly Efficient Catalyst for Epoxidation of Styrene, Chin. J. Catal. 36 (2) (2015) 244-51. https://doi.org/10.1016/S1872-2067 (14) 60221-7

[19] D. Venkatesh, B. B. V. S. Vara Prasad, K. V. Ramesh, M. N. V. Ramesh, Magnetic Properties of $\mathrm{Cu} 2+$ Substituted $\mathrm{Ni}-\mathrm{Zn}$ Nano-Crystalline Ferrites Synthesized in Citrate-Gel Route, Journal of Inorganic and Organometallic Polymers and $\begin{array}{llll}\text { Materials } & 30 & \text { (2020) 2057-2066 }\end{array}$ https://doi.org/10.1007/s10904-019-01419-2

[20] R. D. Waldron, Infrared Spectra of Ferrites. Phys. Rev. $\quad 99 \quad$ (1995) https://doi.org/10.1103/PhysRev.99.17 